RESEARCH ARTICLE

\title{
Drivers of export upgrading: Evidence from panel data for upper-middle and high income groups, low and lower-middle income groups
}

\author{
Naima Chrid \\ Faculty of Economic Sciences and Management of Sfax, Sfax University, Tunisia
}

\section{Check for updates}

Correspondence to: Naima Chrid, Faculty of Economic Sciences and Management of Sfax, Sfax University, Tunisia;

E-mail: nchrid@yahoo.fr

Received: November 13, 2020;

Accepted: January 7, 2021;

Published: January 13, 202

Citation: Chrid N. Drivers of export upgrading: Evidence from panel data for upper-middle and high income groups, low and lower-middle income groups. Front Manage Bus, 2021, 2(1): 63-73. https://doi.org/10.25082/FMB.2021.01.001

Copyright: (C) 2020 Naima Chrid. This is an open access article distributed under the terms of the Creative Commons Attribution License, which permits unrestricted use, distribution, and reproduction in any medium, provided the original author and source are credited.

\begin{abstract}
The objective of this study is to contribute with empirical evidence to the understanding of the determinants of export upgrading measured through two alternative indicators (export complexity level and degree of export diversification) using a cross-country panel dataset over the 1999-2013 period. For this purpose, a panel cointegration framework and two homogeneous subpanels have been considered based on the income level of the sample countries (upper-middle and high income groups, low and lower-middle income groups). Based on the Dynamic OLS (DOLS) and Fully Modified OLS (FMOLS) technique, the results indicate that export upgrading of countries is enhanced by GDP per capita, knowledge creation ( this variable is differentiated into internal knowledge(i.e human capital and research $\&$ development) and external knowledge (i.e Foreign Direct Investment and imports) and Institutional quality. The effects of these determinants vary between low, lower-middle income, upper-middle and high income country.
\end{abstract}

Keywords: export upgrading, determinants of export upgrading, panel cointegration, Dynamic OLS (DOLS), Fully Modified OLS (FMOLS)

\section{Introduction}

In the last several decades, the nature of international trade has been dramatic changes. One of the most important changes is the increasing interconnectedness of production processes across many countries, with each country specializing in particular stages of a good's production sequence. This phenomenon has been called 'slicing up the value chain' or 'fragmentation'. It defined as the splitting of a production process into two or more steps that can be undertaken in different locations but that lead to the same final product [1-3]. It allows countries to specialize in tasks in which they have comparative advantage (Whittaker, et al. 2010; Baldwin, 2011) and participate in the global supply chain. However, it is recognized that not all countries benefit from it. Not all countries are a like in terms of their integration into the global economy.

Actually, several developing countries have undertaken structural reforms that were aimed to improve economic performance through upgrading in the global value chain or moving up the value chain. This concept is defined by Pavlinek and Zenka (2011) [4], Kaplinksy (2004) [5], Humphrey and Schmitz (2002) [6], Porter (2000) [7] as the process by which economic actors nations engaging in the production of higher value-added products, employing more efficient production strategies, and increasing the skill content of activities by firms.

In recent years, small previous literature has emerged, arguing that the key factor of moving up the value chain is the export upgrading strategies. It defined by Gereffi (2005) [8] as the process by which economic actors nations, firms and workers move from low-value to relatively high-value activities in global production networks. It refers to the capacity of a firm to innovate to increase the value added of its products and processes $[6,7,9]$. The literature suggests that export upgrading can have important effects on productivity and economic growth. Countries with more "sophisticated" export bundles appear to grow faster [10, 11]. Indeed, specializing in some products will bring higher growth than specializing in others' [12]. Similar evidence is provided by Jarreau and Poncet (2012) [13] for Chinese provinces; they find that regions specializing in more sophisticated goods subsequently grow faster.

Several studies have examined the determinants of export upgrading. Therefore, it is important to analyze and understanding the main drivers of export upgrading. The literature is not 
abundant in this regard. In fact, there are few studies exploring the factors that are important for understanding changes in export upgrading [15].

The objective of this study is to contribute with empirical evidence to the understanding of the factors that explain export upgrading for 55 countries over the period 1999-2013, using a panel cointegration framework based on DOLS and FMOLS technique.

This paper makes three key contributions to the debate. The first contribution is to provide new empirical evidence within a panel cointegration framework to examine the determinants of export upgrading that takes into account the order of integration of the variables; we apply the panel stationarity test developed by Im-Pesaran-Shin (2003). To estimate what are the major determinants that can contribute to export upgrading, we employed the Dynamic OLS (DOLS) and we used Fully Modified OLS (FMOLS) in order to check the robustness of results. The second contribution is splitting the sample into two different groups of countries: uppermiddle and high income groups, low and lower-middle income groups) depending on the relative ranking of their income per capita. The third contribution refers to the use of two distinctive measures of export upgrading in order to check the robustness of results with respect to a variation in measurement. The first measure is the "economic complexity index" (ECI), developed by Hidalgo and Hausmann (2009). This index measures the degree of diversification and complexity of a country's export basket. A higher value of this index is associated with more sophisticated manufacturing capabilities of the country's production structure (Sweet and Maggio, 2015). The second measure is the Cadot et al. (2011) export diversification index (EDI); where a higher value of the index indicates lower diversification thus it could also be referred to as a measure of export specialization [16].

The remainder of the paper is organized as follows. Section 2 proposes a theoretical framework to analyze the determinants of export upgrading. Section 3 presents data, descriptive statistics, and the empirical methodology. Section 4 discusses the results and Section 5 concludes.

\section{Literature review}

What factors determining export upgrading is the key question of development economy. Several studies has been the focus of empirical investigations for many groups of countries and time periods which authors have researched to examine the factors that can influence export upgrading. In this line of thought, Amighin and Sanfilipp (2014) [17] has applied the Generalized Method of Moments (GMM) for the period between 2003 and 2010 to explain what are the determinant of African exports upgrading measured both as export diversification and increasing export unit values. According to these authors, several factors appear to have contributed positively to export diversification including the level of development of a country, as represented by per capita GDP, exchange rate, imported goods geographical remoteness, inward FDI. But others do matter for export upgrading including the share of domestic investment to GDP, natural resources, inflation rate and term of trade.

In his paper, Sandu and Ciocanel (2014) [18] examined the impact of R \& D on technical upgrading. In their study, they used a panel data for 27 EU countries, during 2006-2010 and employed a linear regression estimation. According to these authors, there is a positive correlation between total R \& D expenditure volume and the level of high-tech exports and the influence of private $\mathrm{R} \& \mathrm{D}$ expenditure on high-tech exports is stronger than public $\mathrm{R} \& \mathrm{D}$ expenditure.

In order to identify the different determinants of export upgrading among countries of different income levels, Zhu and Fu (2013) [15] used 171 countries classified into different groups of countries: low, medium, and high income country over the 1992-2006 period. The results suggest that the export sophistication of countries is enhanced by different factors and its effect vary between each country group. According to Zhu and Fu (2013) [15]. Institutional quality, capital-labor ratio, human capital and R \& D, FDI and imports are an important determinant of export upgrading in the high income country group. In middle income country, capital-labor ratio, institutional quality, FDI and imports facilitate the export upgrading of countries. However, in the low income country group, natural resources and education have a significant positive effect on export sophistication. But, capital intensity do not appear to enhance export upgrading for this group.

Empirical evidence on the main factors of export upgrading is provided by several authors. For example, Alvarez and Bravo-Orteg (2012) [14] analyzed what are the main factors driving export upgrading. In their paper, the authors used a larger dataset for 79 countries around the world covering the period 1962-2000. Using the generalized method of moments (GMM) estimator. They found that trade openness induces higher specialization. Financial development 
does not seem to help countries to diversify their exports. In contrast, exchange rates, human capital accumulation and term of trade have positive effects and contribute positively to diversify exports.

Sharma (2003) [19] explored the factors that are important for understanding changes in export performance in India for the period 1970-1998. Simultaneous equation estimation results revealed that several factors appear to have contributed to this phenomenon. For example, export supply and the real depreciation of the rupee affect positively India's export performance. But foreign investment appears to have statistically no significant impact on export performance although its coefficient has a positive sign.

In a more recent paper, Karagöz (2016) [20] investigated the determinants of Turkey's export performance in a time series setting using the data set covering the period of 1980-2014. Results of the analysis reveal that turkey's export performance has been positively affected by the depreciation of domestic currency. Foreign direct investment and external income level turned out insignificant.

Yi, Wang and Kafouros (2013) [21] examined the determinants of export upgrading. The authors used 30 manufacturing sectors throughout all 31 china's provinces for the period of 2005-2007. Employing a baseline model and the generalized method of moments (GMM), they showed that innovative capabilities are positively associated with export performance. Institutional variables, foreign ownership and marketization have a positive effect on a firm's export performance. In contrast, government relationship and business groups are significant but produce a negative effect on export performance. So, the results explored the joint effect of innovative capabilities and institutional factors on export performance.

Using the generalized method of moments (GMM) for a sample of developing countries covering 2001-2005, Fu and Gong (2010) [22] explored the role of indigenous and foreign innovation efforts on technological upgrading. The empirical evidence suggests that foreign technology transfer may facilitate technology development. R \& D activities at the industry level are found to be the major driver of technology upgrading of indigenous firms that push out the technology frontier. While foreign investment appears to contribute to static industry capabilities. While, R \& D activities of foreign-invested firms have exerted a significant negative effect on the technical change of local firms over the sample period.

Makhlouf, Kellard and Vinogradov (2015) [16], emphasized the importance of trade openness for export diversification. They applied ordinary least squares method for a sample of 116 countries over 35 years (1970 to 2005). The result indicated that openness can be positively associated with export diversification. Using ordinary least squares and a sample of 68 manufacturing firm from 1998 to 2009, Qiu, Ortolano and Wang (2013) argued that technology acquisition, domestic R \& D and government policies have a significant impact on technology upgrading.

In other study, Felipe, Kumar, Abdon and Bacate (2012) applied the method of reflections and used a sample for 124 countries from 2001-2007. They demonstrated that export shares of products of different complexity (in the country's total exports) vary with income per capita: the major exporters of the more complex products are the high-income countries, while the major exporters of the less complex products are the low-income countries.

With a sample of 96 Nigerian manufacturing firm for the year 2005, Adeoti (2012) utilized a logit regression framework and demonstrated that technology investment and firm size have a strong positive relationship with export potential. In other study, Noureen and Mahmood (2014) applied the fully modified ordinary least squares co-integration for a sample of ASEAN and SAARC member countries for the time period 1986 to 2012 . They argued that foreign direct investment, domestic investment, competitiveness, financial sector development and institutional strength are significantly and positively related to export diversification in both the regions.

In a series of recent papers, the link between a country's FDI flows and its ability to upgrade its export structure has long been analyzed by the international trade literature [19,23-25]. The idea that, FDI has an important role in promoting export upgrading is emphasized by a large amount of research. This assumption is explored by Kemeny (2010). In a multi-country study, the author employed the generalized method of moments (GMM) to examine the relationship between inward foreign direct investment and technological upgrading for a panel dataset covering 142 countries (splitting the sample into different groups of countries: low and lower-middle, medium, and high income countries) over the period 1972-2001. The result found that FDI is positively associated with technological upgrading. However, It impact depends on an economy's level of development and social capability. For lower-income countries, upper-middle- and high-income the effect of FDI on technological upgrading is considerably stronger among those endowed with higher levels of social capability. In low- and lower- middle-income countries, industrial upgrading is affected by other factors for example well- educated workforce, infrastructure, greater trust, and effective economic, social and political institutions. 


\section{Model specification and data}

\subsection{Model}

In this study, we examine the major determinants that can affect export upgrading and know does the importance of these determinants vary among countries. We applied the Dynamic ordinary least squares co-integration (DOLS) and fully modified ordinary least squares cointegration (FMOLS) for robustness check purposes.

Specifically, we consider the following linear heterogeneous panel regression models:

$E X P U_{i t}=\alpha_{0}+\gamma_{i}+\theta_{i}+\beta_{1}\left(Y_{i t}\right)+\beta_{2}\left(H C_{i t}\right)+\beta_{3}\left(F D I_{i t}\right)+\beta_{4}\left(R D_{i t}\right)+\beta_{5}\left(M_{i t}\right)+\beta_{6}\left(I_{i t}\right)+\varepsilon_{i t}$

Where $=1, \ldots$, denotes a country index and $=1, \ldots$, denotes the time period. EXPU is the export upgrading indicator, measured by the Cadot et al. (2011) export diversification index (EDI) and the economic complexity index (ECI) developed by Hidalgo and Hausmann (2009). $Y$ is the level of a country's economic growth, measured by the natural logarithm of the real GDP per capita in constant 2005 US dollars. Control variables including, in line with Zhu and $\mathrm{Lu}$ (2013) are classified on knowledge creation via Research and development expenditure \% of GDP (RD) and human capital measured by the share of population enrolled in secondary schooling (HC) and knowledge transfer via FDI (the Foreign direct investment inflows over GDP (FDI) and the imports of goods and services to GDP). The variable I is institutional quality, proxied by the "rule of law index" is a country-specific intercept, is a time dummy, and is the composite error term.

\subsection{Data sources and descriptive statistics}

We use data for a panel of 55 countries over the period 1999-2013 (When we use export diversification index as the export upgrading indicator, the sample period is limited to 1984-2010, since export diversification data from IMF is not available for the more recent period.). Countries are split into two sub-panels based on the World Bank's income classification: upper-middle and high income groups (39), low and lower-middle income groups (16) (See Table 1 for a full list of the countries included in the sample). Data on per capita GDP, Research and development expenditure \% of GDP, the imports of goods and services to GDP, school enrolment, and foreign direct investment inflows as a percentage of GDP come from the World Bank's World Development Indicators database. The economic complexity index is from the MIT's Observatory of Economic Complexity. The export specialization index comes from the International Monetary Fund online database (Aavailable at https://www.imf.org/external/np/res/dfidimf/diversification.htm) and rule of law index is from Descriptive statistics and correlation matrixes between variables are summarized in Tables A3 and A4.

\subsection{Econometric methodology}

The main objective of this paper is to investigate factors that explain export upgrading by applying panel cointegration. The testing procedure involves the following steps: we examine the existence of unit root using the first generation panel unit root test Im-Pesaran-Shin (IPS, 2003). Second we used the panel cointegration test proposed by Pedroni (1999). Once it is established that the panel is subject to a significant long cointegration relationship we employed Dynamic Ordinary Least Squares co-integration (DOLS) and fully modified ordinary least squares co-integration (FMOLS) for robustness check purposes.

\section{Empirical results}

\subsection{Panel unit root tests}

In order to verify that all of the variables are integrated to the same order, we should employ the first generation panel unit root tests of Im-Pesaran-Shin which is denoted IPS (2003). The null hypothesis is that the series contains a unit root. The IPS statistic is based on average of individual Cross-Sectional ADF (CADF) statistics and can be written as follow:

Table 2 mentions the result of unit root tests. It shows that the null hypothesis of the unit roots for the panel is rejected. These results strongly indicate that the variables are non- stationary in the intercept form and stationary when we include time trend at the $1 \%$ significance level for high and low-income sub-panels as well as for the whole panel block. Therefore, this implies that all variables are integrated of order one, i.e. I (1). 
Table 1 Summary statistics

\begin{tabular}{|c|c|c|c|c|c|c|c|c|c|c|c|}
\hline & Mean & Std Dev & Min & $\operatorname{Max}$ & -1 & -2 & -3 & -4 & -5 & -6 & -7 \\
\hline \multicolumn{12}{|c|}{ All countries } \\
\hline LGDP & 0.6161 & 0.8283 & -1.694 & 23.888 & 10.000 & & & & & & \\
\hline ECI & 93.839 & 10.970 & 69.549 & 111.432 & 0.9887 & 10.000 & & & & & \\
\hline FDI & 44.887 & 69.047 & -92.012 & 880.963 & 0.1221 & 0.1522 & 10.000 & & & & \\
\hline M & 381.281 & 180.635 & 83.972 & 100.597 & 0.1135 & 0.0019 & 0.3991 & 10.000 & & & \\
\hline $\mathrm{HC}$ & 94.335 & 233.077 & 134.844 & 165.581 & 0.2609 & 0.5554 & 0.1214 & 0.0612 & 10.000 & & \\
\hline $\mathrm{RD}$ & 12.297 & 10.858 & 0.0307 & 44.074 & 0.7204 & 7304 & 0.0253 & -0.1008 & 0.3920 & 10.000 & \\
\hline I & 0.6879 & 0.9266 & -17.425 & 20.026 & 0.6077 & 0.8749 & 0.1531 & 0.1173 & 0.5399 & 0.0450 & 10.000 \\
\hline \multicolumn{12}{|c|}{$\begin{array}{l}\text { Upper-middle and high } \\
\text {-income groups }\end{array}$} \\
\hline LGDP & 0.0358 & 15.007 & -93.316 & 248.651 & 10.000 & & & & & & \\
\hline ECI & 0.0025 & 0.0037 & -0.0099 & 0.0168 & 0.0699 & 10.000 & & & & & \\
\hline FDI & 11.586 & 22.877 & -31.566 & 543.822 & -0.0037 & -0.0439 & 10.000 & & & & \\
\hline $\mathrm{M}$ & 0.0159 & 0.0887 & -0.2953 & 0.3251 & 0.0565 & 0.2224 & -0.0160 & 10.000 & & & \\
\hline $\mathrm{HC}$ & 0.0103 & 0.6200 & -0.8398 & 0.5437 & 0.0437 & 0.0064 & -0.0163 & 0.0251 & 10.000 & & \\
\hline $\mathrm{RD}$ & 0.0321 & 0.2238 & 0.9562 & 23.596 & -0.0288 & -0.0961 & 0.0014 & 0.0041 & -0.0557 & 10.000 & \\
\hline I & 0.6800 & 19.558 & -68.881 & 44.999 & 0.0012 & 0.0768 & -0.0044 & -0.0438 & 0.1164 & -0.0917 & 10.000 \\
\hline \multicolumn{12}{|c|}{$\begin{array}{l}\text { Low and lower-middle } \\
\text {-income groups }\end{array}$} \\
\hline LGDP & 0.6066 & 0.4802 & -18.460 & 0.3542 & 1.000 & & & & & & \\
\hline ECI & 66.862 & 0.6916 & 54.639 & 78.236 & 0.5627 & 10.000 & & & & & \\
\hline FDI & 40.820 & 60.740 & -24.988 & 45.289 & -0.3104 & -0.1258 & 10.000 & & & & \\
\hline M & 362.062 & 131.920 & 130.542 & 84.006 & -0.1069 & 0.1167 & 0.5158 & 10.000 & & & \\
\hline $\mathrm{HC}$ & 518.652 & 273.030 & 51.648 & 99.338 & 0.4361 & 0.7044 & -0.0342 & 0.2701 & 10.000 & & \\
\hline RD & 0.2691 & 0.2142 & -0.1166 & 0.8410 & 0.3203 & 0.0235 & -0.0306 & 0.2415 & 0.0297 & 10.000 & \\
\hline I & 0.6164 & 42.353 & -11.749 & 171.482 & -0.4178 & -0.3770 & -0.0826 & -0.1047 & -0.1047 & -0.1460 & 10.000 \\
\hline
\end{tabular}

Table 2 Im-Pesaran-Shin IPS (2003) panel unit root test results

\begin{tabular}{|c|c|c|c|c|}
\hline & \multicolumn{2}{|c|}{ Intercept only } & \multicolumn{2}{|c|}{ Intercept and trend } \\
\hline & Statistic & p-value & Statistic & p-value \\
\hline \multicolumn{5}{|c|}{ All countries } \\
\hline ECI & $-5.594 * * *$ & 0.0000 & $-5.594 * * *$ & 0.0000 \\
\hline EDI & $-10.790 * * *$ & 0.0000 & $-11.499 * * *$ & 0.0000 \\
\hline LPIB & 2.526 & 0.9940 & $0.71769 * * *$ & 0.0570 \\
\hline FDI & $-7.050 * * *$ & 0.0000 & $-8.874 * * *$ & 0.0000 \\
\hline M & $-2.960 * * *$ & 0.0015 & $-7.007 * * * *$ & 0.0000 \\
\hline $\mathrm{HC}$ & 1.749 & 0.5994 & $-0.835 * * *$ & 0.2010 \\
\hline $\mathrm{RD}$ & 1.618 & 0.9117 & $-4.434 * * *$ & 0.0000 \\
\hline I & $-2.419 * * *$ & 0.0078 & $-5.375^{* * *}$ & 0.0000 \\
\hline \multicolumn{5}{|c|}{ High income countries } \\
\hline ECI & $-11.837 * * *$ & 0.0000 & $-12.503 * * *$ & 0.0000 \\
\hline EDI & $-1.944 * * *$ & 0.0025 & $-6.0060 * * *$ & 0.0025 \\
\hline LPIB & $-7.470 * * *$ & 0.0000 & $-8.8430 * * *$ & 0.0000 \\
\hline FDI & $-10.396 * * *$ & 0.0000 & $-10.572 * * *$ & 0.0000 \\
\hline M & $-11.666 * * *$ & 0.0000 & $-11.861 * * *$ & 0.0000 \\
\hline $\mathrm{HC}$ & $-7.1240 * * *$ & 0.0000 & $-7.337 * * *$ & 0.0000 \\
\hline $\mathrm{RD}$ & $-10.563 * * *$ & 0.0000 & $-11.288^{* * *}$ & 0.0000 \\
\hline I & $-11.793 * * *$ & 0.0000 & $-11.923 * * *$ & 0.0000 \\
\hline \multicolumn{5}{|c|}{ Low income countries } \\
\hline ECI & $-3.103 * * *$ & 0.0010 & $-4.742 * * *$ & 0.0000 \\
\hline EDI & -0.5446 & 0.2930 & $-2.402 * * *$ & 0.0081 \\
\hline LPIB & 90.3600 & 1.0000 & $-1.667 *$ & 0.0440 \\
\hline FDI & $-1.9120 * *$ & 0.0270 & $-2.643 * * *$ & 0.0041 \\
\hline M & 0.8400 & 0.7990 & $-2.760 * * *$ & 0.0029 \\
\hline $\mathrm{HC}$ & -0.2540 & 0.3991 & $-2.414 * * *$ & 0.0007 \\
\hline $\mathrm{RD}$ & $-3.2790 * * *$ & 0.0005 & $-4.841 * * *$ & 0.0000 \\
\hline I & 1.7420 & 0.959 & $-3.182 * * *$ & 0.0070 \\
\hline
\end{tabular}




\subsection{Panel cointegration test}

We apply the panel cointegration tests proposed by Pedroni (1999). The null hypothesis of this test is no cointegration. Table 3 describes the results of Pedroni's cointegration test. It indicates that for full sample and subgroups of countries most statistics are statistically significant (Panel pp-stat, Paneladf-stat, Group pp-stat and Group adfstat). It shows that the null hypothesis of no cointegration can be rejected at the 5\% significance level. Therefore, they accept the alternative hypothesis of presence of cointegration.

Table 3 Pedronipanel cointegration test results

\begin{tabular}{|c|c|c|c|c|c|c|}
\hline & \multicolumn{2}{|c|}{ All countries } & \multicolumn{2}{|c|}{$\begin{array}{l}\text { High and high-middle } \\
\text { income group }\end{array}$} & \multicolumn{2}{|c|}{$\begin{array}{l}\text { Low and low-middle } \\
\text { income group }\end{array}$} \\
\hline & Test stat & prob & Test stat & prob & Test stat & prob \\
\hline \multicolumn{7}{|c|}{ Export complexity } \\
\hline Panel v-stat & -5.7606 & 1.000 & -5.0443 & 1.0000 & -2.9212 & 0.9983 \\
\hline Panel rho-stat & 7.5215 & 1.000 & 5.6883 & 1.0000 & 2.1769 & 0.9853 \\
\hline Panel pp-stat & $-10.6032 * * *$ & 0.000 & $-5.5863 * * *$ & 0.0000 & $-7.2262 * * *$ & 0.0000 \\
\hline Paneladf-stat & $-2.9530 * * *$ & 0.0018 & $-5.4940 * * *$ & 0.0000 & $-1.5954^{*}$ & 0.0556 \\
\hline Group rho-sta & 10.1121 & 1.000 & 7.9395 & 1.0000 & 4.4582 & 1.0000 \\
\hline Group pp-stat & $-16.8653^{* * *}$ & 0.000 & $8.3814 * * *$ & 0.0000 & $-11.2037 * * *$ & 0.0000 \\
\hline Group adf stat & $-1.4273^{*}$ & 0.0767 & $-3.4500 * * *$ & 0.0000 & $-3.0212 * * *$ & 0.0013 \\
\hline \multicolumn{7}{|c|}{ Export diversification } \\
\hline Panel v-stat & -7.3360 & 1.000 & -4.7159 & 1.0000 & -3.1473 & 0.9992 \\
\hline Panel rho-stat & 6.5740 & 1.000 & 6.8691 & 1.0000 & 4.1702 & 1.0000 \\
\hline Panel pp-stat & $-12.9353 * * *$ & 0.000 & $-11.8363 * * *$ & 0.0000 & $-10.5282 * * *$ & 0.0000 \\
\hline Panel adf-stat & $-2.1138 * *$ & 0.017 & $-5.1856 * * *$ & 0.0000 & $-5.0517 * * *$ & 0.0000 \\
\hline Group rho-sta & 9.7161 & 1.000 & 9.3256 & 1.0000 & 6.0653 & 1.0000 \\
\hline Group pp-stat & $-17.4917 * * *$ & 0.000 & $-18.8696 * * *$ & 0.0000 & $-14.2542 * * *$ & 0.0000 \\
\hline Group adf stat & $-1.7351^{* *}$ & 0.0414 & $-6.4665 * * *$ & 0.0000 & $-4.8610 * * * *$ & 0.0000 \\
\hline
\end{tabular}

\subsection{Panel cointegration regressions}

Several estimation methods have been proposed in the literature to estimate what factors can contribute to industrial upgrading, like the Generalized Method of Moments (GMM), linear regression estimation, ordinary least squares. We used panel cointegration framework. Specifically, we employed the Dynamic ordinary least squares co-integration (DOLS) and fully modified ordinary least squares co-integration (FMOLS) estimators us an appropriate econometric method that can test the major determinants of export upgrading.

Our results are reported under two sub-sections: (a) results for the whole dataset and (b) results when the dataset is split into income level sub-groups. The income level sub- groups were created in order to investigate whether relationships are particularly strong or weak for countries with different levels of income. We ran separate regressions excluding and including variable institutional quality (model 1 and model 2). We also carried out further robustness checks in which we examined whether the general results are robust when the method of measuring key variables is changed.

\section{(1) Empirical analysis of all countries}

Empirical results are represented in Table 4 using two indicators of export upgrading, ECI and EDI, respectively. The main results using export complexity are reported in Panel A of Table 4. The DOLS results (model 1) indicate that GDP per capita has a positive and significant effect on export complexity at the $5 \%$ level. Our results confirm that there is a positive relation between the dgree of complexity and the level of development of a country, as represented by the significant positive coefficient of per capita GDP. This result is consistent with some recent empirical studies [14] (Tadesse and Shukralla, 2013) and confirms that countries at an early stage of development have larger opportunities to diversify.

Similarly, we find a positive and significant impact of research and developpement on export complexity but humain capital has no significant effect. According to this result human capital accumulation tends to reduce export complexity. Also we find that importing from other developing countries has a positive and significant impact on export complexity. This implies that trade impact positively export upgra ding measuring by export complexity. The share of domestic investment to GDP has a negative and significant impact on export diversification, which can be interpreted as a signal of efficient allocation of resources within the economy. 
The estimated coefficients of institutional quality as proxied by the rule of law are negative and statistically significant.

The panel DOLS results for model 2 suggested that expect for FDI, all other variable exerted a significant positive effect on industrial upgrading. The estimated results using the FMOLS method are broadly consistent with the estimates from the panel DOLS with the exception that the coefficients of variables FDI and I become positive and insignificant. As regards the impact of our variables of interest on export upgrading, we find GDP per capita has the strongest impact on export complexity using DOLS and FMOLS methods.

Panel B of Table 4 reports the estimations for export diversification index as a second proxy for export upgrading, The result are broadly similar to the ones presented using export complexity index but we find that GDP per capita has a statistically insignificant positive effect on export specialization. Regarding the control variables, we find a positive relation between the degree of diversification and Knowledge creation activities, as represented by the significant positive coefficient of research and developpement but humain capital has negative and statistically significant effect. FDI and imports also demonstrate a significant negative effect on the export complexity index. Institutional quality also shows a significant negative effect on export complexity.

When we excluding quality institution (model 2), we find that the level of development of a country continue to contribute positively on the degree of diversification as represented by the significant positivecoefficient of per capita GDP (FMOLS).

Table 4 DOLS and FMOLS estimate sresults

\begin{tabular}{|c|c|c|c|c|c|c|c|c|}
\hline & \multicolumn{4}{|c|}{ Panel A: ECI as an export upgrading indicator } & \multicolumn{4}{|c|}{ Panel B: EDI as an export upgrading indicator } \\
\hline & \multicolumn{2}{|c|}{ DOLS } & \multicolumn{2}{|c|}{ FMOLS } & \multicolumn{2}{|c|}{ DOLS } & \multicolumn{2}{|c|}{ FMOLS } \\
\hline & Model 1 & Model 2 & Model 1 & Model 2 & Model 1 & Model 2 & Model 1 & Model 2 \\
\hline \multirow{2}{*}{ LGDP } & $0.3107 * *$ & $0.2370^{* * *}$ & $0.1245^{* * *}$ & -0.1422 & 0.1236 & -0.3383 & -0.2693 & $0.5481 * * *$ \\
\hline & $(0.035)$ & $(0.006)$ & $(0.003)$ & $(0.172)$ & $(0.2674)$ & $(0.617)$ & $(0.418)$ & $(0.000)$ \\
\hline \multirow{2}{*}{ FDI } & $-0.0081 * *$ & $-0.0102 * * *$ & 0.0048 & $0.0155^{* * *}$ & -0.0035 & -0.0362 & -0.0164 & -0.0026 \\
\hline & $(0.012)$ & $(0.000)$ & $(0.3364)$ & $(0.0017)$ & $(0.1474)$ & $(0.017)$ & $(0.027)$ & $(0.497)$ \\
\hline \multirow{2}{*}{$\mathrm{CH}$} & -0.0008 & 0.0009 & $-0.0066^{* *}$ & $0.2865 * * *$ & $-0.0031 *$ & 0.0016 & 0.0010 & -0.0058 \\
\hline & $(0.655)$ & $(0.386)$ & $(0.0327)$ & $(0.007)$ & $(0.0594)$ & $(0.877)$ & $(0.836)$ & $(0.967)$ \\
\hline \multirow{2}{*}{ RD } & $0.4685^{* * *} *$ & $0.4453^{* * *}$ & $0.3373 * * *$ & $0.3512 * * *$ & 0.0397 & 0.0214 & 0.1180 & -0.0525 \\
\hline & $(0.000)$ & $(0.000)$ & $(0.001)$ & $(0.0038)^{* * *}$ & $(0.6546)$ & $(0.968)$ & $(0.653)$ & $(0.692)$ \\
\hline \multirow{2}{*}{ M } & $0.0113^{* * *} *$ & $0.0090^{* * *}$ & -0.0012 & $-0.0054 * * *$ & $-0.0040 * * *$ & 0.0179 & 0.0094 & $-0.0037^{*}$ \\
\hline & $(0.000)$ & $(0.000)$ & $(0.3854)$ & $(0.0032)$ & $(0.0876)$ & $(0.298)$ & $(0.175)$ & $(0.0637)$ \\
\hline \multirow{2}{*}{ I } & -0.0863 & & 0.0172 & & $-0.2570 * * *$ & & $-0.4367 *$ & \\
\hline & $(0.4747)$ & & $(0.6968)$ & & $(0.000)$ & & $(0.069)$ & \\
\hline
\end{tabular}

Note: $* * * * *$ and $*$ denote significance levels at the $1 \%, 5 \%$, and $10 \%$, respectivel

\section{(2) Empirical analysis of sub-groups by income level}

In order to identify the different impacts of determinants on export upgrading among countries of different income levels, we classify all sample countries into two sub-samples: a high and middle income group (HM: including the upper-middle and high income groups) and a low and middle income group (LM: including low and lower-middle income groups). Details of the country classification and a list of countries in each category are given in Table 5.

Table 6 reports the estimated results for these country groups. For the HM income country group, the estimated coefficient of GDP per capita is positive and statistically significant. This finding, which is consistent with those Felipe, Kumar, Abdon and Bacate (2012) implies that countries that export shares of products of different complexity (in the country's total exports) vary with income per capita: the major exporters of the more complex products are the highincome countries. This variable has a positive but insignificant coefficient in LM countries. This imply that for these countries the GDP per capitat is not a significant determinant of their export upgrading. Human capital appears to play a positive role in upgrading the export complexiy in the LM income group. However, the effect of R \& D is not statistically significant in these countries. On the contrary, R \& D plays a statistically significant role in the upgrading of export sophistication in high income countries but higher education has a negative and significant effect on industrial upgrading in these countries. This result may be surprising in light of the importance attached to human capital for the level of export complexity. This evidence is in ligne with those of Zhu and Fu (2013) [15], who find that higher education does not show any significant effect on export sophistication level. The estimated coefficient of FDI is negative and statistically significant in both the LM and the HM countries. The result suggesting that for this countries, FDI exerted a significant negative effect on industrial upgrading. However, 
Table 5 Sample countries and groups by income

\begin{tabular}{|c|c|c|c|}
\hline $\begin{array}{l}\text { Low income } \\
\text { economies }\end{array}$ & $\begin{array}{l}\text { Lower middle Income } \\
\text { economies }\end{array}$ & $\begin{array}{l}\text { Upper Middle income } \\
\text { economies }\end{array}$ & $\begin{array}{l}\text { High income } \\
\text { economies }\end{array}$ \\
\hline $\begin{array}{l}\text { Congo, Dem, Rep } \\
\text { Madagascar } \\
\text { Mozambique } \\
\text { Tanzania } \\
\text { Uganda }\end{array}$ & $\begin{array}{l}\text { Bolivia } \\
\text { Cameroon } \\
\text { Egypt } \\
\text { Ecuador } \\
\text { Guatemala } \\
\text { Mangolia } \\
\text { Marroco } \\
\text { Pakistan } \\
\text { Paraguay } \\
\text { Peru } \\
\text { Philippines } \\
\text { Sri Lanka } \\
\text { Zambia }\end{array}$ & $\begin{array}{l}\text { Algeria } \\
\text { Bulgaria } \\
\text { China } \\
\text { Colombia } \\
\text { Costa Rica } \\
\text { Malaysia } \\
\text { Mauritus } \\
\text { Mexico } \\
\text { Panama } \\
\text { Romania } \\
\text { South Africa } \\
\text { Thailand } \\
\text { Tunisia } \\
\text { Turkey }\end{array}$ & $\begin{array}{l}\text { Australia } \\
\text { Austria } \\
\text { Belgium } \\
\text { Canada } \\
\text { Chile } \\
\text { Finland } \\
\text { France } \\
\text { Greece } \\
\text { Irland } \\
\text { Israel } \\
\text { Italy } \\
\text { Japon } \\
\text { Netherlunds } \\
\text { New Zealand } \\
\text { Norway } \\
\text { Poland } \\
\text { Spain } \\
\text { Sweden } \\
\text { Trinidad and Tobag } \\
\text { United States } \\
\text { Uruguay }\end{array}$ \\
\hline
\end{tabular}

Imports have a robust and statistically significant effect in the HM countries yet not in the LM country group. This suggests that imports are important drivers of export upgrading in high income countries. The result indicates a negative relationship between institutional quality and export upgrading in both HM and LM countries. This result is interesting and contrary to the normal expectation, it shows that countries with higher scores for "rule of law" and "political stability" appear to have achieved lower levels of export upgrading If we excluding quality institutional (model 2), the results can be summaries as flow. GDP per capital continue to contribute positively to export upgrading both for HM and LM countries croup. It is the key determinant of industrial upgrading. Knowledge creation activities such as human capital and R $\&$ D investment show a consistent and robust positive impact on export upgrading for LM and HM. Specially, Humain capital has a positive and significant impact on industrial upgrading for HM countries. In contrast international knowledge such as FDI and imports exerted a negative and significant effect on industrial upgrading for low income countries.

If we consider the export diversification index as a proxy for export upgrading, the results in Panel B of Table 6 show that for the high-income panels are broadly similar to the ones presented using export complexity index and point to a positive and significant relationship between economic growth and export upgrading. This finding suggests for the HM, export diversification significantly depends on its GDP per capita. This finding suggests a positive relation between the degree of diversification and the level of development of a country, as represented by the significant positive coefficient of per capita GDP. This result is consistent with some recent empirical studies [14]. The DOLS results show that, unlike the HM, GDP per capita has a negative effect on export diversification. The coefficient estimate implies that a $1 \%$ increase in GDP per capita reduces export diversification by around 0.610 . Most of the explanatory variables have a positive signs. Knowledge creation activities such as human capital and R \& D seem to favour export upgrading in HM and LM. As regards variables related to external knowledge such as FDI and imports also demonstrate a positive effect on the export diversification index in high income countries. Finally, we do not find any significant effect of institutional quality proxied by the rule of law index on export diversification in high income countries. However, this variable has a negative and significant effect in low income countries suggesting that countries with lower scores for "rule of law" and "political stability" can't achieve higher levels of export diversification .Excluding This variable (model 2) the results, showing similar determinants of export diversification as those observed in model 1. An interesting exception is the import coefficient, which affect negatively and significantly export diversification. For the low- income-countries panel, an interesting result is represented by the impact of the per capita GDP which suggests that this variable has a negative impact on export diversification. This result implies that GDP per capita does not seem to help low income countries to diversify their exports. 
Table 6 DOLS estimates results upper-middle and high income groups, low and lower-middle income groups

\begin{tabular}{|c|c|c|c|c|c|c|c|c|}
\hline & \multicolumn{4}{|c|}{ Panel A: ECI as an export upgrading indicator } & \multicolumn{4}{|c|}{ Panel B: EDI as an export upgrading indicator } \\
\hline & \multicolumn{2}{|c|}{$\begin{array}{l}\text { High and high-middle } \\
\text { income group }\end{array}$} & \multicolumn{2}{|c|}{$\begin{array}{l}\text { Low and low-middle } \\
\text { income group }\end{array}$} & \multicolumn{2}{|c|}{$\begin{array}{l}\text { High and high-middle } \\
\text { income group }\end{array}$} & \multicolumn{2}{|c|}{$\begin{array}{l}\text { Low and low-middle } \\
\text { income group }\end{array}$} \\
\hline & Model 1 & Model 2 & Model 1 & Model 2 & Model 1 & Model 2 & Model 1 & Model 2 \\
\hline LGDP & $\begin{array}{l}0.6651 \text { *** } \\
(0.000)\end{array}$ & $\begin{array}{l}11.558 \\
(0.721)\end{array}$ & $\begin{array}{l}0.1265 \\
(0.708)\end{array}$ & $\begin{array}{l}0.3050 \\
(0.370)\end{array}$ & $\begin{array}{l}0.0535^{* *} \\
(0.030)\end{array}$ & $\begin{array}{l}0.7727 * * \\
(0.028)\end{array}$ & $\begin{array}{l}-0.6109 \\
(0.335)\end{array}$ & $\begin{array}{l}-0.7478 * * * \\
(0.360)\end{array}$ \\
\hline FDI & $\begin{array}{l}-0.0119 * * * \\
(0.000)\end{array}$ & $\begin{array}{l}-0.0104 * * * \\
(0.000)\end{array}$ & $\begin{array}{l}-0.0162 \\
(0.056)\end{array}$ & $\begin{array}{l}-0.118 \\
(0.160)\end{array}$ & $\begin{array}{l}0.0080 \\
(0.155)\end{array}$ & $\begin{array}{l}0.0115 \\
(0.047)\end{array}$ & $\begin{array}{l}0.0553 * * * \\
(0.004)\end{array}$ & $\begin{array}{l}-0.0073 \\
(0.768)\end{array}$ \\
\hline $\mathrm{CH}$ & $\begin{array}{l}-0.0065^{* * * *} \\
(0.000)\end{array}$ & $\begin{array}{l}9.8110 * * * \\
(0.000)\end{array}$ & $\begin{array}{l}0.0076 \\
(0.284)\end{array}$ & $\begin{array}{l}0.0029 \\
(0.670)\end{array}$ & $\begin{array}{l}0.0027 \\
(0.484)\end{array}$ & $\begin{array}{l}0.0019 \\
(0.702)\end{array}$ & $\begin{array}{l}0.0047^{*} \\
(0.080)\end{array}$ & $\begin{array}{l}0.0041 \\
(0.783)\end{array}$ \\
\hline $\mathrm{RD}$ & $\begin{array}{l}0.3938 * * * \\
(0.000)\end{array}$ & $\begin{array}{l}0.2302 \\
(0.627)\end{array}$ & $\begin{array}{l}0.5426 \\
(0.162)\end{array}$ & $\begin{array}{l}0.7945 \\
(0.041)^{* * *}\end{array}$ & $\begin{array}{l}0.1257 \\
(0.538)\end{array}$ & $\begin{array}{l}0.1571 \\
(0.550)\end{array}$ & $\begin{array}{l}0.3257 \\
(0.631)\end{array}$ & $\begin{array}{l}-0.6725 \\
(0.439)\end{array}$ \\
\hline M & $\begin{array}{l}0.0126 * * * \\
(0.000)\end{array}$ & $\begin{array}{l}2.8579 * * \\
(0.017)\end{array}$ & $\begin{array}{l}-0.0105 \\
(0.066)\end{array}$ & $\begin{array}{l}-0.0112 * * * \\
(0.049)\end{array}$ & $\begin{array}{l}0.0010 \\
(0.573)\end{array}$ & $\begin{array}{l}-0.0005 \\
(0.298)\end{array}$ & $\begin{array}{l}0.0483 * * * \\
(0.000)\end{array}$ & $\begin{array}{l}0.0617 * * * \\
(0.000)\end{array}$ \\
\hline I & $\begin{array}{l}-0.2330 * * \\
(0.021)\end{array}$ & & $\begin{array}{l}-0.0359 \\
(0.035)\end{array}$ & & $\begin{array}{l}0.0866 \\
(0.681)\end{array}$ & & $\begin{array}{l}-1.1085^{* * *} \\
(0.003)\end{array}$ & \\
\hline
\end{tabular}

Note: $* * * * *$ and $*$ denote significance levels at the $1 \%, 5 \%$, and $10 \%$, respectivel

\subsection{Robustness checks}

To check the robustness of our results we estimate our model using fully modified ordinary least square (FMOLS). Table 7 reports estimations the Results of fully modified ordinary least square (FMOLS) method. These results present some similarities with those obtained with DOLS method. Both for complexity and diversification, GDP per capita shows a significantly positive coefficient for high and low income countries. The impact of inward FDI, import and humain capital continue to have a positive impact, and the accumulation of human capital is more favourable to diversification. This conclusion implies that countries with higher education can take advantage to develop new export. There appears to be an inverse relationship between institutional quality and export upgrading. In the case of the high-income countries panel, institutional quality to affect both export complexity and diversification upgrading negatively but for low income countries, it has a positive but not significant effect on export upgrading measuring by export complexity and export diversification.

Table 7 FMOLS estimates results upper-middle and high income groups, low and lower-middle income groups

\begin{tabular}{|c|c|c|c|c|c|c|c|c|}
\hline & \multicolumn{4}{|c|}{ Panel A: ECI as an export upgrading indicator } & \multicolumn{4}{|c|}{ Panel B: EDI as an export upgrading indicator } \\
\hline & \multicolumn{2}{|c|}{$\begin{array}{l}\text { High and high-middle } \\
\text { income group }\end{array}$} & \multicolumn{2}{|c|}{$\begin{array}{l}\text { Low and low-middle } \\
\text { income group }\end{array}$} & \multicolumn{2}{|c|}{$\begin{array}{l}\text { High and high-middle } \\
\text { income group }\end{array}$} & \multicolumn{2}{|c|}{$\begin{array}{l}\text { Low and low-middle } \\
\text { income group }\end{array}$} \\
\hline & Model 1 & Model 2 & Model 1 & Model 2 & Model 1 & Model 2 & Model 1 & Model 2 \\
\hline LGDP & $\begin{array}{l}0.1980 * * * \\
(0.0041)\end{array}$ & $\begin{array}{l}34.858 * * * \\
(0.000)\end{array}$ & $\begin{array}{l}0.3884 * * \\
(0.017)\end{array}$ & $\begin{array}{l}0.3820^{* *} \\
(0.019)\end{array}$ & $\begin{array}{l}0.6597 * * * \\
(0.000)\end{array}$ & $\begin{array}{l}0.2713 * * * \\
(0.000)\end{array}$ & $\begin{array}{l}-0.4414 \\
(0.1251)\end{array}$ & $\begin{array}{l}0.4850 \\
(0.1010)\end{array}$ \\
\hline FDI & $\begin{array}{l}0.0001 \\
(0.504)\end{array}$ & $\begin{array}{l}0.036 \\
(0.549)\end{array}$ & $\begin{array}{l}-0.012 * * * \\
(0.003)\end{array}$ & $\begin{array}{l}-0.0029 \\
(0.416)\end{array}$ & $\begin{array}{l}0.0074 \\
(0.1064)\end{array}$ & $\begin{array}{l}-0.1801^{* * * *} \\
(0.000)\end{array}$ & $\begin{array}{l}-0.0150 \\
(0.1229)\end{array}$ & $\begin{array}{l}-0.0147 \\
(0.140)\end{array}$ \\
\hline $\mathrm{CH}$ & $\begin{array}{l}0.0029 * * * \\
(0.0014)\end{array}$ & $\begin{array}{l}0.7521^{* * * *} \\
(0.000)\end{array}$ & $\begin{array}{l}-0.0022 \\
(0.530)\end{array}$ & $\begin{array}{l}-0.0029 * * * \\
(0.002)\end{array}$ & $\begin{array}{l}-0.0027 \\
(0.352)\end{array}$ & $\begin{array}{l}-0.0310 \\
(0.398)\end{array}$ & $\begin{array}{l}-0.0214 * * * \\
(0.000)\end{array}$ & $\begin{array}{l}0.0201 * * * \\
(0.001)\end{array}$ \\
\hline $\mathrm{RD}$ & $\begin{array}{l}-0.1343^{* *} \\
(0.013)\end{array}$ & $\begin{array}{l}-0.2399 * * * \\
(0.000)\end{array}$ & $\begin{array}{l}0.5234 * * * \\
(0.008)\end{array}$ & $\begin{array}{l}0.5324 * * * \\
(0.007)\end{array}$ & $\begin{array}{l}0.0665 \\
(0.993)\end{array}$ & $\begin{array}{l}-0.1658 * * * \\
(0.000)\end{array}$ & $\begin{array}{l}-0.0186 \\
(0.944)\end{array}$ & $\begin{array}{l}-0.1197 \\
(0.662)\end{array}$ \\
\hline M & $\begin{array}{l}0.0003 \\
(0843)\end{array}$ & $\begin{array}{l}0.6870 * * * \\
(0.000)\end{array}$ & $\begin{array}{l}0.0037 \\
(0.136)\end{array}$ & $\begin{array}{l}0.0041 \\
(0.118)\end{array}$ & $\begin{array}{l}-0.0061 \\
(0.0138)\end{array}$ & $\begin{array}{l}-0.0454 * * * \\
(0.0014)\end{array}$ & $\begin{array}{l}0.0001 \\
(0.9660)\end{array}$ & $\begin{array}{l}-0.0001 \\
(0.976)\end{array}$ \\
\hline I & $\begin{array}{l}-0.0336 \\
(0.563)\end{array}$ & & $\begin{array}{l}0.1372 \\
(0.210)\end{array}$ & & $\begin{array}{l}-0.0255 \\
(0.681)\end{array}$ & & $\begin{array}{l}-0.3832 * * \\
(0.0206)\end{array}$ & \\
\hline
\end{tabular}

Note: $* * *, * *$ and $*$ denote significance levels at the $1 \%, 5 \%$, and $10 \%$, respectivel

\section{Conclusions}

Using a large dataset of countries during the period between 1999-2013, this study analyses the role of several potential determinants of export upgrading. We explore the role of several factors, and we use two alternative indicators of export upgrading. (Export complexity level and degree of export diversification.)

In order to identify the different impacts of determinants on export sophistication among countries of different income levels, we used 55 countries splitting into two sub-samples: a high 
and middle income group (including the upper-middle and high income groups) and a low and middle income group (including low and lower-middle income groups). For this purpose, a panel cointegration framework has been employed using DOLS and FMOLS methods.

The results of panel unit root tests suggest that all the variables are integrated to the same order I (1). Besides, the cointegration tests yield evidence of a long-run relationship between and export upgrading (proxied by export complexity index or by export diversification index) and economic growth, FDI, human capital, research and developpement, imports and quality institution.

Our results indicate that GDP per capita has a positive and significant effect on export upgrading for the full-sample and high-income panels, while this effect is negative and significant for low-income countries. Also, we conclude that economic growth continues to affect export complexity the major exporters of the more complex products are the high- income countries., with a larger magnitude than that found in the full-sample model. More precisely, the long-run coefficient of the export complexity index in high-income-countries panel $(0.665)$ is found to be approximately two times larger than the full-sample panel coefficient $(0.337)$. This may suggest a stronger long-run relationship between export complexity and growth in high income countries than in middle- and low-income countries.

We look at the effect of institutional quality, we find that contrary the normal perspective on the role of institutional quality, this variable do matter for export upgrading in high income countries. However, its effect differs in countries with different income levels. Interestingly, low income countries with lower scores in "rule of law" and "political stability" have achieved a higher level of export upgrading.

As regards the internal knowledge creation (human capital and R \& D) serve as important sources of indigenous knowledge creation, contributing directly to the export upgrading of countries. The effect of humain capital is significant in the low income country group while the effect of R \& D is significant for high income countries. However external knowledge transfer (FDI) and imports were found to have positive impacts on the export upgrading of countries. The effect of FDI is positive but not significant across different country groups. The effect of imports is more robust and significant for low income countries. Our main results suggest the importance of external knowledge in the improvement of the export upgrading of countries.

\section{References}

[1] Deardorff AV. Fragmentation in Simple Trade Models. Discussion Paper, 1998: 422. http://www.spp.umich.edu/rsie/workingpapers/wp.html

[2] Jones RW and Kierzkowski. Globalization and the Consequences of International Fragmentation. Manuscript. University of Rochester and Graduate Institute of International Studies, Geneva. 1997.

[3] Helg R and Tajoli L. Patterns of international fragmentation of production and the relative demand for labor. North American Journal of Economics and Finance, 2005, 16: 233-254. https://doi.org/10.1016/j.najef.2005.02.002

[4] Pavlinek P and Zenka J. Upgrading in the automotive industry: firm-level evidence from Central Europe. Journal of Economic Geography, 2011, 11(4): 559-586. https://doi.org/10.1093/jeg/lbq023

[5] Kaplinksy R. Spreading the gains from globalization: what can be learned from value chain analysis? Problems of Economic Transition, 2004, 47: 74-115.

[6] Humphrey J and Schmitz H. How Does Insertion in Global Value Chains Affect Upgrading in Industrial Clusters? Regional Studies , 2002, 9: 1017-1027. https://doi.org/10.1080/0034340022000022198

[7] Porter M. The Competitive Advantage of Nations Contract. Report on the value chain of the telecommunications equipment sector Proprietary and confidential property, 2007.

[8] Gereffi G. The global economy: Organization, governance and development. 2005, 160-182 in Neil J. Smelser and Richard Swedberg (eds.), Handbook of Economic Sociology, 2nd ed. Princeton, NJ: Princeton University Press and Russell Sage Foundation. https://doi.org/10.1515/9781400835584.160

[9] Kaplinsky R, Morris M and Readman J. The globalization of product markets and immiserizing growth: lessons from the South African Furniture Industry. World Development, 2002, 30: 11591178 . https://doi.org/10.1016/S0305-750X(02)00029-3

[10] Hausmann R, Hwang J and Rodrik D. What you export matters. Journal of Economic Growth, 2007, 12( 1$): 1-25$ https://doi.org/10.1007/s10887-006-9009-4

[11] Minondo A. Exports quality-adjusted productivity and economic growth. Journal of International Trade and Economic Development, 2010, 19( 2): 257-287. https://doi.org/10.1080/09638190802573071 
[12] Lall S. The technological structure and performance of developing country manufactured exports, 1985-98. Oxford Development Studies, 2010, 28(3): 337- 369.

https://doi.org/10.1080/713688318

[13] Jarreau J and Poncet S. Export sophistication and economic growth: Evidence from China. Journal of Development Economics, 2012, 97: 281-292. https://doi.org/10.1016/j.jdeveco.2011.04.001

[14] Agosin1 MR, Alvarez R and Bravo-Ortega C. Determinants of Export Diversification Around the World: 1962-2000. The World Economy, 2012, 35(3): 295-315. https://doi.org/10.1111/j.1467-9701.2011.01395.x

[15] Fu XL and Zhu SJ. Drivers of Export Upgrading. World Development, 2013, 51: 221-233. https://doi.org/10.1016/j.worlddev.2013.05.017

[16] Makhlouf Y, Kellard NM and Vinogradov D. Trade openness, export diversification, and political regimes. Economics Letters, 2015, 136: 25-27. https://doi.org/10.1016/j.econlet.2015.08.031

[17] Amighini A and Sanfilippo M. Impact of South-South FDI and Trade on the Export Upgrading of African Economies. World Development, 2014, 64: 1-17. https://doi.org/10.1016/j.worlddev.2014.05.021

[18] Sandu S and Ciocanel B. Impact of R\& D and Innovation on high-tech export. Procedia Economics and Finance, 2014, 15: 80-90. https://doi.org/10.1016/S2212-5671(14)00450-X

[19] Sharma K. Factors determining India's export performance. Journal of Asian Economics, 2003, 4: 435-446. https://doi.org/10.1016/S1049-0078(03)00036-8

[20] Karagöz K. Determining Factors of Turkey's Export Performance: An Empirical Analysis, Procedia Economics and Finance, 2016, 38: 446-457. https://doi.org/10.1016/S2212-5671(16)30216-7

[21] Yi I, Wang CQ and Kafouros M. The effects of innovative capabilities on exporting: Do institutional forces matter? International Business Review, 2013, 22: 392-406. https://doi.org/10.1016/j.ibusrev.2012.05.006

[22] Fu XL and Gong YD. Indigenous and Foreign Innovation Efforts and Drivers of Technological Upgrading: Evidence from China. World Development 2011, 39(7): 1213-1225. https://doi.org/10.1016/j.worlddev.2010.05.010

[23] Sargent $\mathrm{O}$ and Matthews L. The drivers of evolution/upgrading in Mexico's maquiladoras: How important is subsidiary initiative? Journal of World Business, 2006, 41: 233-246. https://doi.org/10.1016/j.jwb.2006.06.001

[24] Zhao Q and Niu MY. Influence analysis of FDI on China's industrial structure optimization, Procedia Computer Science, 2013, 17: 10151022. https://doi.org/10.1016/j.procs.2013.05.129

[25] Kementy T. Does Foreign Direct Investment Drive Technological Upgrading? World Development, 2010, 38(11): 1543-1554. https://doi.org/10.1016/j.worlddev.2010.03.001 